\title{
Animal models for inflammatory mucosal disease and their potential for studying the microbiome in chronic rhinosinusitis*
}

Christian A. Lux', Richard G. Douglas², Do-Yeon Cho³, Michael W. Taylor', Kristi Biswas ${ }^{2}$

' School of Biological Sciences, University of Auckland, Auckland, New Zealand

2 School of Medicine, Department of Surgery, University of Auckland, Auckland, New Zealand

${ }^{3}$ Department of Otolaryngology Head and Neck Surgery, University of Alabama at Birmingham, Birmingham, AL, USA
Rhinology Online, Vol 2: 69 - 80, 2019 http://doi.org/10.4193/RHINOL/19.015

*Received for publication:

March 26, 2019

Accepted: May 6, 2019

Published: May 19, 2019

\begin{abstract}
Chronic rhinosinusitis (CRS) is a morbid condition of the paranasal sinuses which severely impairs patients' quality of life. CRS represents one of the leading diseases that are responsible for antibiotic prescriptions. However, there is little evidence to support the efficacy of antibiotics in CRS. Due to the highly heterogeneous nature of CRS determining the underlying etiology is challenging. The mucosal microbiome has been hypothesised to play a role in the pathophysiology of CRS.

Several attempts to establish a representative model of CRS have been made to help determine the pathogenesis of this condition. This review summarises the current literature on model systems for inflammatory sinus disease. Fourteen different studies are discussed, including mouse, rabbit and sheep as model organisms. A detailed description of the methods for model development and examples for their application are provided. Focus is put on animal models that should be suitable for studying the sinonasal microbiome in CRS. To date, only two studies sought to employ their model for microbiome analysis. Other models are included for which there is currently no microbiome information, however they are of potential use in this regard and we thus discuss their suitability.

This review identifies a need for further employment of animal models of CRS for microbiome research. Recently, a rabbit model of CRS featuring several qualities that make it particularly suitable for microbiological research has been described. This model system represents a further advance of translational research in the field of CRS.
\end{abstract}

Key words: animal model, chronic rhinosinusitis, microbiome, rabbit model, rhinosinusitis

\section{Animal models for studying CRS}

Animal models represent an important tool in biomedical research ${ }^{(1)}$. They have been successfully applied to extend our knowledge of and to develop new treatments for chronic respiratory diseases such as cystic fibrosis ${ }^{(2)}$ and asthma ${ }^{(3)}$. Chronic rhinosinusitis (CRS) is a globally prevalent inflammatory condition affecting the paranasal sinuses ${ }^{(4)}$ and afflicts $\sim 5 \%$ of people ${ }^{(5-7)}$. It is a highly heterogeneous disease, which has made it challenging to determine the underlying aetiology. Good animal models should accurately reflect the pathophysiology of this disease. Many microorganisms, such as Staphylococcus aureus ${ }^{(8,9)}$, Corynebacterium tuberculostearicum, Corynebacterium accolens ${ }^{(10,11)}$ and members of the genus Fusobacterium, have been implicated in the pathogenesis of this chronic condition ${ }^{(12,}$ 13). However, there is increasing evidence that bacterial dysbiosis (i.e. deleterious shifts in the microbiota) is a feature of CRS and can influence the host inflammatory response ${ }^{(13-15)}$. The evidence for a role of the mucosal microbiome in the pathophysiology of this disease has recently been summarised in a comprehensive review ${ }^{(16)}$.

In standard practice, CRS is initially treated with a combination of corticosteroids and antibiotics ${ }^{(17,18)}$. In 2013, sinusitis was the diagnosis which accounted for the most outpatient prescripti- 
ons for antibiotics in the US, and CRS accounted for two thirds of the prescriptions under this diagnosis ${ }^{(19)}$. However, there is surprisingly little evidence to support the efficacy of antibiotics in CRS ${ }^{(20)}$, and their routine use is not recommended in several clinical guidelines ${ }^{(21-24)}$. It is timely to examine the practice of antibiotic treatment for CRS.

To help determine the pathogenesis of CRS, several attempts to establish a representative animal model have been made (e.g. sheep, rabbits, murine species). Potential applications for both basic and translational research highlight the importance of such models for a better understanding of complex diseases such as CRS ${ }^{(25)}$. New insights relating to innate immunity and CRS derived solely from animal-based research demonstrate the power of animal models for the study of this disease (26). Experimental animal models are particularly important when investigating specific scientific questions that are more difficult to approach in human subjects. Human samples studies demonstrated marked differences of microbial communities between various studies. The causes of such variation are poorly understood, but could include differences among populations of patients (e.g., antibiotic history, ethnicity), methodology, genetics, environmental factors etc. ${ }^{12)}$. Experimental methodologies such as targeted genetic modifications ${ }^{(27,28)}$ and the use of investigative therapeutics can be studied first in animal models (29-32). Additionally, the use of animal model systems allows a higher level of experimental control around antecedent medical interventions and personal factors such as smoking and diet that cannot be easily achieved in human studies. Various studies endorse the significant role of animal models in the process of understanding pathogenesis and pathophysiology of CRS 25,26 , 33). However, as with all animal models, caution should be exercised when drawing conclusions about human disease.

Different in vitro cellular model systems of CRS have been used to provide non-sentient alternatives ${ }^{(34)}$. However, the sinus mucosa involves a pseudostratified epithelium comprising various differentiated cells, which means that cell-based models cannot replicate the complex role of the nasal mucous membrane in CRS. A 2015 review article concluded that in vitro models for studying CRS are generally not recommended ${ }^{(35)}$. Cell lines for the study of CRS are few and a search through the American Type Culture Collection and the European Collection of Cell Cultures identified only one relevant CRS cell line. However, even that cell line, RPMI 2650, shows an atypical phenotype that differs from patient-derived primary cells in terms of cellular morphology and reaction to inflammatory stimulation ${ }^{(35)}$. Notwithstanding the limitations of current in vitro model systems, new cell culturing techniques have the potential to be powerful tools for the future investigation of host-microbe interactions in inflammatory nasal disease in humans ${ }^{(36)}$.

\section{Current animal models for inflammatory mucosal diseases}

Studies of sinusitis involving animal models dates back to 1941

(37). Early experimental sinus surgeries were performed on dogs

(38) before Hilding (1941) developed the first animal model of sinusitis in rabbits ${ }^{(37)}$. Many different methods have subsequently been used to establish acute and chronic sinus inflammation in animals.

This review summarises a total of 14 studies that employed various animal species and experimental techniques to create inflammatory conditions in the nasal cavities; four studies used mice, two used sheep and eight utilised rabbits (Table 1). Animal models of true CRS (inflammation lasting for a minimum period of 12 weeks) are very few. This review article includes models for acute sinonasal inflammation since they share similarities with many CRS models and the experimental techniques are fundamentally identical. The studies were chosen as being representative of different approaches of model development. Selection was based on their potential or prior application in microbiomerelated studies, if applicable. Additional criteria regarding the success rate of different modelling techniques and methods for the validation of successfully established models, as well as the induced disease status, were adopted.

A number of animal species have been used for the study of sinonasal and airway inflammation in diseases such as bronchitis, cystic fibrosis, allergic rhinitis, acute rhinosinusitis and CRS. The species studied include sheep ${ }^{(39-42)}$, pigs ${ }^{(43)}$, rodents such as guinea pigs ${ }^{(44,45)}$, rats ${ }^{(46)}$ and mice ${ }^{(47-49)}$ as well as ferrets ${ }^{(50)}$ and rabbits ${ }^{(33,51,52)}$. One study also examined the suitability of mink as an animal model for studying Pseudomonas aeruginosa sinusitis ${ }^{(53)}$. Rodents constitute the most commonly used CRS animal models with mice being chosen most often. The main method to induce rhinosinusitis in mice is by the administration of antigens such as allergens or inflammatory agents. Rabbits are also considered to be suitable models. It is of note that rabbits are not rodents but rather, together with hares and pikas, comprise their own order Lagomorpha. A wide range of approaches has been tried to induce sinonasal diseases in rabbits, including bacterial or fungal inoculation, administration of inflammatory reagents and occlusion of the sinus ostia. Interestingly, sheep can develop chronic inflammatory conditions without any experimental intervention if the flock is infected with nasal parasites such as the nasal bot fly. Techniques to induce rhinosinusitis in sheep include challenges to the immune system, nasal obstruction and inoculation of microorganisms to the sinus mucosa.

\section{Mouse models}

Rodents are generally considered suitable for the investigation of sinus diseases ${ }^{(54)}$. Mice are easy to breed and to maintain in the laboratory and the experimental application of mouse 
Table 1. A selection of previously used animal models of CRS and rhinosinusitis.

\begin{tabular}{|c|c|c|c|c|c|c|c|}
\hline Study & Technique & $\begin{array}{l}\text { Invasive, } \\
\text { microbes, } \\
\text { antigens }\end{array}$ & $\begin{array}{l}\text { Interven- } \\
\text { tion/ Devel- } \\
\text { opmental } \\
\text { period }\end{array}$ & Disease status & $\begin{array}{l}\text { Detection } \\
\text { method }\end{array}$ & $\begin{array}{l}\text { Ani- } \\
\text { mals/ } \\
\text { treat- } \\
\text { ment } \\
\text { group }\end{array}$ & Success rate \\
\hline \multicolumn{8}{|l|}{ Mouse } \\
\hline $\begin{array}{l}\text { Lindsay et } \\
\text { al., } 2006\end{array}$ & $\begin{array}{l}\text { Systemic sensitisation with } A \text {. } \\
\text { fumigatus extract followed by } \\
\text { intranasal } A \text {. fumigatus extract } \\
\text { application }\end{array}$ & $\begin{array}{l}\text { No, } \\
\text { No, } \\
\text { Yes }\end{array}$ & $\begin{array}{l}12 \text { weeks/ } \\
12 \text { weeks }\end{array}$ & CRS & Histology & 35 & $\begin{array}{l}100 \% \\
\text { Control group (PBS } \\
\text { treatment): } 0 \%\end{array}$ \\
\hline $\begin{array}{l}\text { Abreu et } \\
\text { al., } 2012\end{array}$ & $\begin{array}{l}\text { Oral antibiotics }(\mathrm{A}) \text {, } \\
\text { intranasal inoculation with } C \text {. } \\
\text { tuberculostearicum }(\mathrm{B}) \text {, } \\
\text { antibiotics + bacterial inocula- } \\
\text { tion (C) }\end{array}$ & $\begin{array}{l}\text { No, } \\
\text { Yes, } \\
\text { No }\end{array}$ & $\begin{array}{l}5-8 \text { days/ } \\
9 \text { days }\end{array}$ & Rhinosinusitis & $\begin{array}{l}\text { Histology, } \\
\text { qPCR }\end{array}$ & 5 & $\begin{array}{l}\text { Group average only } \\
\text { for signs of rhinosi- } \\
\text { nusitis: } \\
\text { A: none } \\
\text { B: moderate } \\
\text { C: significant } \\
\text { Control group (no } \\
\text { treatment): none }\end{array}$ \\
\hline $\begin{array}{l}\text { Kim et al., } \\
2014\end{array}$ & $\begin{array}{l}\text { Intranasal: } \\
\text { PBS alone (A), } \\
\text { protease from A. oryzae com- } \\
\text { bined with OVA (B), } \\
\text { protease alone }(C)\end{array}$ & $\begin{array}{l}\text { No, } \\
\text { No, } \\
\text { Yes }\end{array}$ & $\begin{array}{l}5 \text { weeks/ } \\
5 \text { weeks }\end{array}$ & $\begin{array}{l}\text { Allergic rhinosi- } \\
\text { nusitis }\end{array}$ & $\begin{array}{l}\text { Histology, } \\
\text { IHC }\end{array}$ & $\begin{array}{l}\text { A: } 3 \\
\text { B: } 5 \\
\text { C: } 5\end{array}$ & $\begin{array}{l}\text { A: } 0 \% \\
\text { B: } 100 \% \\
\text { C: } 60 \% \\
\text { Control group (PBS } \\
\text { treatment): } 0 \%\end{array}$ \\
\hline $\begin{array}{l}\text { Khalmura- } \\
\text { tova et al., } \\
2016\end{array}$ & $\begin{array}{l}\text { Systemic sensitisation with HDM } \\
\text { extract plus intranasal HDM (A), } \\
\text { Systemic sensitisation with HDM } \\
\text { extract plus intranasal HDM and } \\
\text { SEB (B), Systemic sensitisation } \\
\text { with OVA plus intranasal OVA } \\
\text { and SEB (C) }\end{array}$ & $\begin{array}{l}\text { No, } \\
\text { No, } \\
\text { Yes }\end{array}$ & $\begin{array}{l}12 \text { weeks/ } \\
12 \text { weeks }\end{array}$ & $\begin{array}{l}\text { CRS with nasal } \\
\text { polyps }\end{array}$ & $\begin{array}{l}\text { Histology, } \\
\text { IHC, } \\
\text { Quantification } \\
\text { of inflammatory } \\
\text { markers }\end{array}$ & 5 & $\begin{array}{l}\text { A: } 0 \% \\
\text { B: } 60 \% \\
\text { C: } 80 \% \\
\text { Control group (PBS } \\
\text { treatment): } 0 \%\end{array}$ \\
\hline \multicolumn{8}{|l|}{ Rabbit } \\
\hline $\begin{array}{l}\text { Marks, } \\
1997\end{array}$ & $\begin{array}{l}\text { Insertion of } \text { Merocel }^{\circledR} \text { infected } \\
\text { with S. pneumoniae into the } \\
\text { nasal cavity }\end{array}$ & $\begin{array}{l}+, \\
\text { Yes, } \\
\text { No }\end{array}$ & $\begin{array}{l}\text { Once/ } \\
2 \text { weeks }\end{array}$ & Rhinosinusitis & $\begin{array}{l}\text { Histology, } \\
\text { Bacterial cultu- } \\
\text { ring }\end{array}$ & 12 & $\begin{array}{l}83 \% \\
\text { Control: } 0 \%\end{array}$ \\
\hline $\begin{array}{l}\text { Dufour, } \\
2005\end{array}$ & $\begin{array}{l}\text { Inoculation with } A \text {. fumigatus (A), } \\
\text { Inoculation with } A \text {. fumigatus } \\
\text { and mucosal injury (B), } \\
\text { Inoculation with } A \text {. fumigatus } \\
\text { and ostial occlusion (C) }\end{array}$ & $\begin{array}{l}+++, \\
\text { Yes, } \\
\text { No }\end{array}$ & $\begin{array}{l}\text { Once/ } \\
\text { 2-4 weeks }\end{array}$ & $\begin{array}{l}\text { Fungal rhinosi- } \\
\text { nusitis }\end{array}$ & $\begin{array}{l}\text { Histology, } \\
\text { Bacterial and } \\
\text { fungal culturing, } \\
\text { Endoscopic exa- } \\
\text { mination }\end{array}$ & $\begin{array}{l}\text { A: } 10 \\
\text { B: } 10 \\
\text { C: } 14\end{array}$ & $\begin{array}{l}\text { A: } 0 \% \\
\text { B: } 20 \% \\
\text { C: } 57 \% \\
\text { Control: } 0 \%\end{array}$ \\
\hline $\begin{array}{l}\text { Liang, } \\
2008\end{array}$ & $\begin{array}{l}\text { Insertion of Merocel }{ }^{\circledR} \text { into nasal } \\
\text { cavity with }(A) \text { and without prior } \\
\text { injection of PMA (B) } \\
\text { Administration of PMA alone (C) }\end{array}$ & $\begin{array}{l}+, \\
\text { No, } \\
\text { Yes/No }\end{array}$ & $\begin{array}{l}\text { Once for } 2 \\
\text { weeks (rever- } \\
\text { sible) } \\
\text { / } 12 \text { weeks }\end{array}$ & CRS & $\begin{array}{l}\text { CT, } \\
\text { Endoscopic exa- } \\
\text { mination, } \\
\text { Bacterial cultu- } \\
\text { ring }\end{array}$ & $\begin{array}{l}\text { A: } 10 \\
\text { B: } 12 \\
\text { C: } 10\end{array}$ & $\begin{array}{l}\text { A: } 70 \% \\
\text { B: } 50 \% \\
\text { C: } 60 \% \\
\text { Control: } 16.3 \%\end{array}$ \\
\hline $\begin{array}{l}\text { Sejima et } \\
\text { al., } 2010\end{array}$ & $\begin{array}{l}\text { Sensitisation with OVA followed } \\
\text { by bilateral occlusion of maxil- } \\
\text { lary sinus with cotton wool and } \\
\text { tissue glue. Further injection of } \\
\text { OVA followed by administration } \\
\text { of saline solution (A), VGSG (B), } \\
\text { PLA (C) }\end{array}$ & $\begin{array}{l}+++ \\
\text { No, } \\
\text { Yes }\end{array}$ & $\begin{array}{l}8 \text { weeks/ } \\
8 \text { weeks }\end{array}$ & Polyposis & Histology & 6 & $\begin{array}{l}\text { A: } 0 \% \\
\text { B: } 33 \% \\
\text { C: } 50 \% \\
\text { Control group (no } \\
\text { treatment): } 0 \%\end{array}$ \\
\hline $\begin{array}{l}\text { Gocea et } \\
\text { al., } 2013\end{array}$ & $\begin{array}{l}\text { Insertion of } \text { Merocel }^{\circledR} \text { into nasal } \\
\text { cavity after injection of PMA (as } \\
\text { described by Liang, 2008) }\end{array}$ & $\begin{array}{l}+, \\
\text { No, } \\
\text { Yes }\end{array}$ & $\begin{array}{l}\text { Once for } 2 \\
\text { weeks (rever- } \\
\text { sible) } \\
\text { / } 12 \text { weeks }\end{array}$ & CRS & $\begin{array}{l}\text { Histology, } \\
\text { Macroscopic } \\
\text { examination }\end{array}$ & 22 & $\begin{array}{l}100 \% \\
\text { Control: } 0 \%\end{array}$ \\
\hline $\begin{array}{l}\text { Miglia- } \\
\text { vacca et } \\
\text { al., } 2014\end{array}$ & $\begin{array}{l}\text { Occlusion of maxillary sinus os- } \\
\text { tium through maxillary sinus (A), } \\
\text { Occlusion of middle meatus } \\
\text { through roof of nasal cavity (B) }\end{array}$ & $\begin{array}{l}+++, \\
\text { No, } \\
\text { No }\end{array}$ & $\begin{array}{l}\text { Once/ } \\
12 \text { weeks }\end{array}$ & CRS & $\begin{array}{l}\text { Histology, } \\
\text { Macroscopic } \\
\text { examination, } \\
\text { Bacterial cultu- } \\
\text { ring }\end{array}$ & 8 & $\begin{array}{l}\text { A: } 100 \% \\
\text { Control: } 0 \% \\
\text { B: } 37.5 \% \\
\text { Control: } 0 \%\end{array}$ \\
\hline
\end{tabular}




\begin{tabular}{|c|c|c|c|c|c|c|c|}
\hline Study & Technique & $\begin{array}{l}\text { Invasive, } \\
\text { microbes, } \\
\text { antigens }\end{array}$ & $\begin{array}{l}\text { Interven- } \\
\text { tion/ Devel- } \\
\text { opmental } \\
\text { period }\end{array}$ & Disease status & $\begin{array}{l}\text { Detection } \\
\text { method }\end{array}$ & $\begin{array}{l}\text { Ani- } \\
\text { mals/ } \\
\text { treat- } \\
\text { ment } \\
\text { group }\end{array}$ & Success rate \\
\hline $\begin{array}{l}\text { Jia et al., } \\
2014\end{array}$ & $\begin{array}{l}\text { Placement of gelatin sponge } \\
\text { into the maxillary sinus and } \\
\text { inoculation with biofilm-forming } \\
\text { S. aureus }\end{array}$ & $\begin{array}{l}+++ \\
\text { Yes, } \\
\text { No }\end{array}$ & $\begin{array}{l}\text { Once/ } \\
4-8 \text { weeks }\end{array}$ & $\begin{array}{l}\text { Sinusitis with } \\
\text { biofilms }\end{array}$ & $\begin{array}{l}\text { Histology, } \\
\text { Electron micro- } \\
\text { scopy }\end{array}$ & 20 & $\begin{array}{l}100 \% \\
\text { Control group (no } \\
\text { inoculation): } 0 \%\end{array}$ \\
\hline $\begin{array}{l}\text { Cho et al., } \\
2018\end{array}$ & $\begin{array}{l}\text { Insertion of } \mathrm{Meroce}^{\circledR} \text { into the } \\
\text { middle meatus under endosco- } \\
\text { pic guidance }\end{array}$ & $\begin{array}{l}+, \\
\text { No, } \\
\text { No }\end{array}$ & $\begin{array}{l}\text { Once for } 2 \\
\text { weeks (rever- } \\
\text { sible)/ } \\
14 \text { weeks }\end{array}$ & CRS & $\begin{array}{l}\text { Histology, } \\
\text { Micro CT }\end{array}$ & 9 & $\begin{array}{l}100 \% \\
\text { Control: } 0 \%\end{array}$ \\
\hline \multicolumn{8}{|l|}{ Sheep } \\
\hline $\begin{array}{l}\text { Ha et al., } \\
2007\end{array}$ & $\begin{array}{l}\text { S. aureus inoculation (A), } \\
\text { Sinus obstruction (B), } \\
\text { S. aureus inoculation plus sinus } \\
\text { obstruction (C) }\end{array}$ & $\begin{array}{l}+++ \\
\text { Yes, } \\
\text { No }\end{array}$ & $\begin{array}{l}\text { Once/ } \\
1 \text { week }\end{array}$ & $\begin{array}{l}\text { Sinusitis with } \\
\text { biofilms }\end{array}$ & $\begin{array}{l}\text { CLSM, } \\
\text { SEM, } \\
\text { TEM }\end{array}$ & $\begin{array}{l}\text { A: } 12^{*} \\
\text { B: } 10^{*} \\
\text { C: } 12^{*}\end{array}$ & $\begin{array}{l}\text { A: } 75 \% \\
\text { B: } 80 \% \\
\text { C: } 83 \% \\
\text { Control group (no } \\
\text { treatment): } 0 \%\end{array}$ \\
\hline $\begin{array}{l}\text { Boase et } \\
\text { al., } 2011\end{array}$ & $\begin{array}{l}\text { Sensitisation with fungal } \\
\text { antigens ( } 4 \text { weeks), occlusion of } \\
\text { frontal ostium and inoculation } \\
\text { with: } \\
\text { A. fumigatus (A), } \\
\text { A. alternata (B), } \\
\text { A. fumigatus + S. aureus (C), } \\
\text { A. alternata + S. aureus (D), } \\
\text { S. aureus (E) }\end{array}$ & $\begin{array}{l}+++, \\
\text { Yes, } \\
\text { Yes }\end{array}$ & $\begin{array}{l}\text { Once after } \\
\text { sensitisation/ } \\
4 \text { weeks and } \\
10 \text { days }\end{array}$ & $\begin{array}{l}\text { Sinusitis with } \\
\text { biofilms }\end{array}$ & $\begin{array}{l}\text { Histology, } \\
\text { CLSM, } \\
\text { Bacterial and } \\
\text { fungal culturing }\end{array}$ & $\begin{array}{l}\text { A: } 6 \\
\text { B: } 6 \\
\text { C: } 5 \\
\text { D: } 5 \\
\text { E: } 4\end{array}$ & $\begin{array}{l}\text { A: } 17 \% \\
\text { B: } 0 \% \\
\text { C: } 100 \% \\
\text { D: } 60 \% \\
\text { E: } 0 \% \\
\text { Control group (PBS } \\
\text { treatment): } 0 \%\end{array}$ \\
\hline
\end{tabular}

$+++=$ highly invasive, $+=$ slightly invasive; $\mathrm{IHC}=$ immunohistochemistry; PMA = phorbol 12-myristate 13-acetate; $C$. tuberculostearicum =

Corynebacterium tuberculostearicum; S. pneumoniae = Streptococcus pneumoniae; S. aureus = Staphylococcus aureus; OVA = ovalbumin, VGSG = valineglycine-serine-glutamic acid; PLA = poly-L-arginine; control = contralateral sinus; HDM = house dust mite; SEB = Staphylococcus aureus enterotoxin $\mathrm{B} ; \mathrm{A}$. oryzae = Aspergillus oryzae; . fumigatus = Aspergillus fumigatus; A alternata $=$ Alternaria alternata; $\mathrm{CT}=\mathrm{computed}$ tomography; $\mathrm{CLSM}=\mathrm{confocal}$ laser scanning microscopy; SEM = scanning electron microscopy; TEM = transmission electron microscopy; ${ }^{*}=$ each sinus was separately randomised to one of the groups.

models has been extensively documented. Mouse models also allow the use of genetically modified animals which represents a significant advantage for the study of disease pathogenesis (55). Providing a wide array of genetic modifications, such animal models are generally employed to address highly specific research questions in the field of mucosal inflammation. For instance, important factors in immunological pathways ${ }^{(56,57)}$ and micro anatomical structures ${ }^{(58,59)}$ are analysed rather than investigating a link between genetic modifications and host microbiome.

While sharing some pathophysiological similarities with human sinuses, mice differ in their sinonasal anatomy. Mice are limited for their use as an in vivo model as they do not reproduce key aspects of human airway physiology, including delayed mucociliary clearance with loss of the cystic fibrosis transmembrane conductance regulator (CFTR) gene and response to CFTR potentiators ${ }^{(2)}$. Mice lack a true sinus, which is essential for the investigation of the pathophysiological mechanisms of CRS ${ }^{(55)}$. Furthermore, immune responses in mice are quite different from those in humans ${ }^{(51)}$. For example, existing evidence suggests that rabbits and swine may be closer to humans than mice concerning toll-like receptor 4 sequences and its function ${ }^{(60)}$. In contrast, rats develop a considerable amount of submucosal gland throughout their airways, which is similar to humans and is thought to represent significant underlying pathology in airway diseases (e.g. cystic fibrosis) ${ }^{(61)}$. Relative to their murine counterparts, rat models are appreciably larger, which enables the sampling of larger tissue specimens and ameliorates the mechanistic limitations of smaller models ${ }^{(62)}$. However, a CFTR knockout rat model (Rattus norvegicus; SD-CFTRtm1sage) generated by Sigma Advanced Genetic Engineering (SAGE, St. Louis, MO, USA) Labs in collaboration with researchers at the University of Alabama at Birmingham, did not appear to develop spontaneous sinusitis ${ }^{(63)}$.

Currently, the most common method to induce rhinosinusitis in mice is by the administration of antigenic substances, which triggers an immune response including the activation of immune cells and production of various immunoglobulins and cytokines. Allergenic substances such as house dust mite extracts (HDM), Staphylococcus enterotoxin B (SEB), ovalbumin 
(OVA), Aspergillus proteases and extracts have been used to challenge an organism's immune system, thus eliciting local inflammatory reactions. Khalmuratova et al. (2016) intranasally stimulated mice with different combinations of HDM extract, SEB and OVA continuously for a period of 12 weeks to establish CRS with a success rate of $60-80 \%{ }^{(47)}$. Kim et al. (2014) successfully induced rhinosinusitis in five out of five animals by intranasally administering a combination of OVA and proteases from Aspergillus oryzae for a period of five weeks ${ }^{(49)}$. Expanding the intervention period for this technique to 12 weeks resulted in additional formation of polypoid lesions in six out seven mice ${ }^{(64)}$. In another study, 35 mice were treated with A. fumigatus extract for 12 weeks, resulting in a chronic inflammatory condition in all of the animals ${ }^{(55)}$. A different method to create a unilateral rhinosinusitis mouse model was used by Jacob et al. (2001). Instead of presenting antigens they obstructed the sinus ostia with Merocel $^{\circledR}$ (nasal packaging material) and surgically administered Bacteroides fragilis, causing a local inflammation of the sinonasal mucosa after four weeks ${ }^{(65)}$. Administration of inflammatory reagents has been established as a powerful tool to create a specific phenotype of CRS in mice, namely CRS with nasal polyps (CRSwNP). These animal models have thus been widely applied for studies on understanding nasal polypogenesis ${ }^{(66)}$ and molecular immune responses in CRSwNP (48, 67-71). Up to this point, no mouse model of CRS has been employed for microbiological research. However, Abreu et al. (2012) used a murine model of sinusitis to investigate $C$. tuberculostearicum as a potential pathogenic influence on the sinus microbiota. By inoculating C. tuberculostearicum into the nasal cavity with and without preceding antibiotic treatment, this study showed the capability of $C$. tuberculostearicum to induce rhinosinusitis, particularly in conjunction with an impaired host sinus microbiota. Co-instillation of C. tuberculostearicum with Lactobacillus sakei, a known probiotic species that is associated with a healthy sinus mucosa, resulted in a reduced abundance of $C$. tuberculostearicum. Additionally, no significant signs of sinus inflammation were observed, indicating that $L$. sakei is a potential probiotic for the sinonasal epithelium ${ }^{(10)}$. This study highlights the clinical relevance of probiotic treatment for mucosal inflammation in the sinuses. The potential therapeutic effects of probiotics on mucosal airway diseases are summarised in a recent review ${ }^{(72)}$.

\section{Rabbit models}

Rabbit models have considerable advantages over mouse models ${ }^{(73)}$. Rabbits are easier to handle than larger model animals, as well as being cheaper to accommodate and maintain. In addition, rearing facilities and surgical procedures are less elaborate and expensive than in larger animals, but easier to perform than in rodents. When working with animal models it is also important to consider ethical regulations. Rodents and rabbits belong to the small animal category that solely requires the approval



Figure 1. Comparison of human and rabbit sinus anatomy. Half views of the paranasal sinuses of rabbit and human are shown (light blue = septum).

of the local animal ethics committee. By contrast, larger animals require approval from a central committee and their use is more strictly regulated. A downside to rabbit models of CRS is a lack of readily available rabbit-specific medication and more limited experimental data on rabbits compared to mice ${ }^{(73)}$. However, rabbits have pertinent advantages over other animal models of CRS, most notably a closer anatomical similarity to human sinuses ${ }^{(65,67,69)}$ (Figure 1), as well as a larger size of the nasal cavity compared to that of rodents. Rabbits are typically docile and easy to work with. The larger size of rabbits' sinuses also makes it easier to perform experimental interventions on them. Additionally, immunologic reactions in rabbits are very similar to those of human responses ${ }^{(51)}$, a feature that is crucial for a successful model of inflammatory mucosal disease. Typical evidence of a direct immune response such as immunocyte infiltration (e.g. eosinophils and neutrophils) ${ }^{(51,54,74)}$, as well as secondary histopathological markers, including squamous metaplasia, fibrosis and goblet cell hyperplasia ${ }^{(75)}$, have been observed in rabbit models of CRS. The function of toll-like receptor 4 in rabbits resembles the human immune response more closely than mice ${ }^{(60)}$.

A range of approaches has been adopted to induce sinonasal inflammation in rabbits. Bacterial or fungal inoculation required a developmental period of two to eight weeks after a single infection event, resulting in cases of acute rhinosinusitis rather than CRS ${ }^{(33,76-78)}$. Success rates ranged from 0-100 \% and depended on the combination of the microbial inoculation with other manipulations (Table 1). While nasal administration of inflammatory reagents is the most common method to induce rhinosinusitis in mice, some studies describe similar approaches with rabbits. Attempts to induce polyposis in rabbits by injecting ovalbumin 


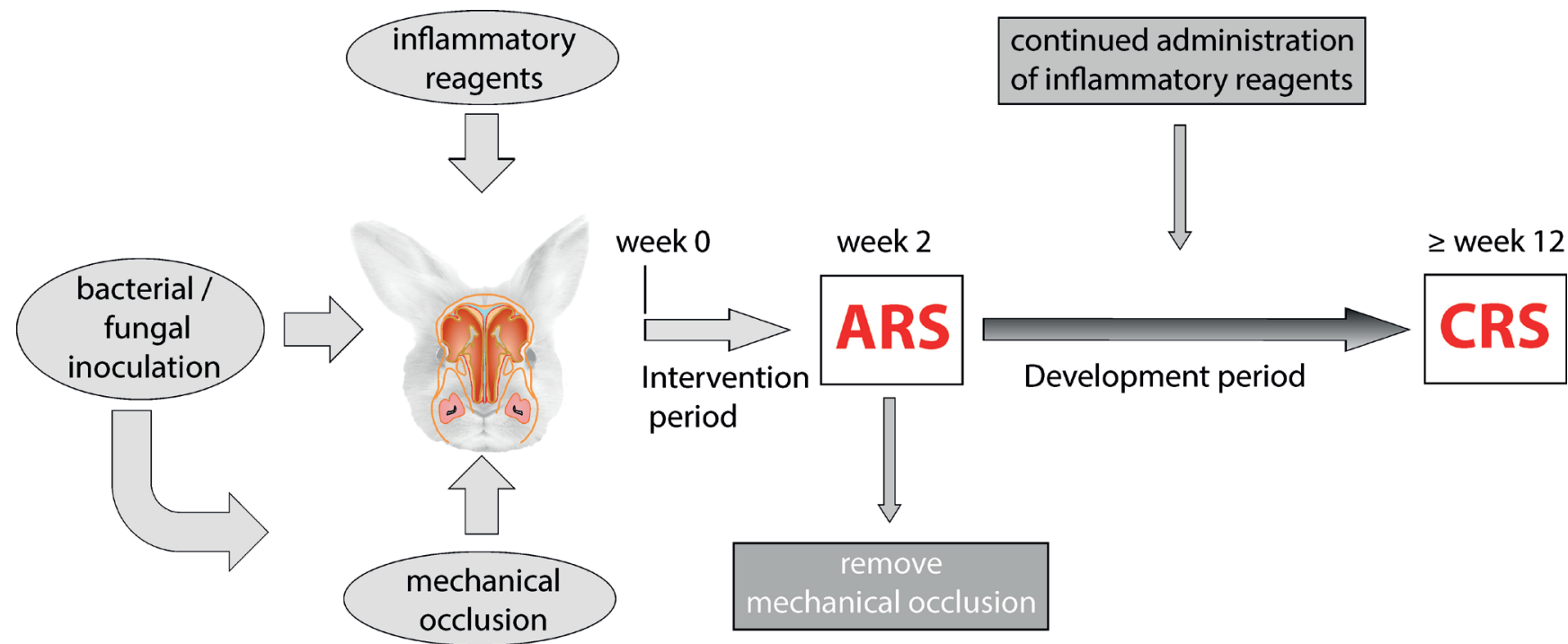

Figure 2. Experimental techniques for the development of acute rhinosinusitis (ARS) and CRS in animal models. Rabbit's sinus anatomy is shown. Methods can be used alone or in combination. Grey arrows indicate how each method can be applied to induce acute or chronic sinonasal inflammation. Bacterial or fungal inoculation is most commonly applied in combination with mechanical occlusion (curved arrow). A two week intervention period is shown as example.

into the occluded maxillary sinuses were not successful ${ }^{(79)}$. Additional application of valine-glycine-serine-glutamic acid, a peptide that stimulates eosinophils, or poly-L-arginine, a substance with the ability to induce airway hyper-responsiveness, resulted in polyp formation in $33 \%$ and $50 \%$ of test animals respectively. However, in that study histological examination focused on polyp formation only and no assessment of mucosal inflammation was reported ${ }^{(79)}$. Other studies have included the administration of OVA and bacterial proteases ${ }^{(80)}$ or bacterial toxoids ${ }^{(54)}$, and reported acute inflammation and mild purulent inflammation of the mucous membrane.

For the development of CRS in rabbits, mechanical occlusion has become the most commonly used method as it is cost effective and does not require additional microbiological perturbation. This approach has been applied in several different variations. For example, in one study the nasal cavities were obstructed unilaterally using bath sponge, cyanoacrylate and peripheral venous blood from the animal itself. After 15 days, acute inflammatory processes in the treated sinus could be observed in 13 out of 15 animals, which was verified histologically by measuring clusters of neutrophils and eosinophils and loss of lining cells. Only two rabbits in the group treated with peripheral venous blood showed no signs of inflammation ${ }^{(54)}$. Liang and colleagues (2008) reversibly blocked one of the animals' nasal cavities with Meroce $^{\circledR}$ for two weeks, in the process establishing CRS in $50 \%$ of rabbits. When combining the Meroce ${ }^{\circledR}$ treatment with injection of phorbol 12-myristate-13-acetate (PMA), an activator of protein kinase $C$ and a potent tumour promoter, the success rate was increased to $70 \%$. Sixteen percent of untreated sinuses also showed signs of inflammatory reaction. Gocea et al. (2013) subsequently applied the combined Merocel $^{\circledR}$ and PMA technique to induce CRS with a $100 \%$ success rate, with no inflammation in the control sinuses ${ }^{(30)}$. In contrast, Migliavacca et al. (2014) refrained from using packing material and performed a more precise but highly invasive surgical occlusion on the sinus. In the first group the maxillary sinus ostium was obstructed through the maxillary sinus and in the second group the middle meatus was occluded through the roof of the nasal cavity. After 12 weeks, CRS was observed in all animals from the first group whereas only $37.5 \%$ of the second group developed CRS ${ }^{(52)}$. In summary, most strategies for the development of CRS in rabbit models have included mechanical occlusion in combination with either microbial inoculation or antigen administration ${ }^{30,33,}$ $51,54,78)$ until Cho et al. (2017) developed a rabbit model of CRS by blocking the middle meatus without inoculating any antigens or microbes which is explained in detail in the next chapter. A comparison of the model techniques shown in Table 1 supports the hypothesis that occlusion of the sinus ostia is the crucial step ${ }^{(81)}$.

Some of the described models were developed over short time periods of 2-8 weeks, thus representing acute rather than chronic forms of sinus disease (Figure 2). Liang's CRS model (2008) has been applied by Gocea and colleagues (2013) to test new treatment strategies to improve wound healing after ESS ${ }^{(30)}$. Another study featured an antibiotic-coated sinus stent to establish an improved route for drug application in CRS patients ${ }^{(82)}$. The therapeutic efficacy of this sinus stent has been investi- 
gated in a preclinical rabbit model of Pseudomonas aeruginosa sinusitis ${ }^{(83)}$.

\section{Sheep models}

As rabbits and rodents are susceptible to mortality due to stress, some studies have employed sheep as model animals being more robust, especially after surgical interventions ${ }^{(54)}$. In addition, sheep show patterns of sinus diseases similar to those of humans ${ }^{(84,85)}$ and their sinonasal anatomy resembles that of

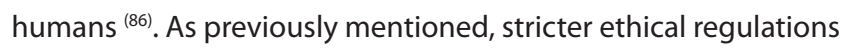
and more expensive housing facilities for larger animals represent downsides of using sheep.

Techniques to induce rhinosinusitis in sheep include challenges to the immune system, nasal obstruction with packing material and inoculation of microorganisms to the sinus mucosa. However, to date no studies have replicated all the features of human CRS by applying these methods. One study used ESS to perform one of the following treatments in sinuses of 24 sheep: infect sheep sinuses with Staphylococcus aureus, obstruct the sinus airways with cotton pledgets or use both methods in combination (87). After one week of blockage or infection or both, rhinosinusitis with biofilm formation was observed in $75 \%, 80 \%$ and $83 \%$ of sinuses, respectively. Boase and colleagues (2011) sensitised sheep sinuses with a fungal antigen prior to occlusion with gauze. Additionally, sinuses were inoculated with either a fungal (A. fumigatus) or bacterial (S. aureus) culture, inducing rhinosinusitis with a success rate of only $17 \%$ and $0 \%$, respectively. Using a combination of fungal and bacterial inoculum increased the success rate to $100 \%{ }^{\left({ }^{40}\right)}$. Importantly, sheep can develop chronic inflammatory conditions without any experimental intervention. One early study utilised this concept to develop rhinosinusitis secondarily to infestation with the nasal bot fly (Oestrus ovis) ${ }^{(84)}$. This model has been used to standardise diagnostic criteria for eosinophilic CRS in sheep ${ }^{(85)}$ and has further been applied for research on mucosal wound healing following ESS ${ }^{(88)}$.

\section{A potential model for microbiome research}

Despite the large variety of different rhinosinusitis models and their applications, only two studies to date have employed a model to study the sinonasal microbiota ${ }^{(10,89)}$. Microbial dysbiosis has been recently hypothesised to play a crucial role in the process of chronic mucosal inflammation ${ }^{(14)}$ and a recent meta-analysis found that the bacterial community of CRS patients is significantly less diverse than that of healthy controls (13). An ideal model for studying the microbiota would feature several key characteristics: firstly, replicating the chronic nature of CRS is essential. Secondly, CRS has to be induced without additional inoculation with bacteria or fungi, to ensure that mucosal inflammation develops naturally. The development of pneumonia or middle ear infections caused by the bacte- rial infection descending into the lower airways has also been reported ${ }^{(78)}$. With the removal of the bacterial inoculum from the experimental protocol, it can be presumed that the risk of causing pneumonia or middle ear infections decreases. Refraining from administering any antigenic reagents additionally ensures that CRS develops in a physiologic manner and that the model shows a distinctive immune response that is driven by rhinogenic inflammation rather than exogenous inflammatory agents. All of these considerations leave obstruction of the sinus passages as the method of choice to induce inflammation of the mucous membrane. Ideally, a minimally invasive and reversible approach towards sinus occlusion is favoured so that the sinuses maintain their natural anatomical structures. This is achieved by obstructing the sinus using nasal packing material, such as Merocel $^{\oplus}$, a polyvinyl alcohol sponge (Medtronic), instead of surgical procedures as described by Migliavacca et al. ${ }^{(52)}$. Lastly, the animal model should be unilateral, so that the contralateral side can be used as a control.

An improved Merocel $^{\circledR}$ obstructing method has recently been described ${ }^{(89)}$. In contrast to Liang et al. (2008), rabbit sinuses were occluded by the exact placement of Merocel $^{\circledR}$ into the opening of the middle meatus, the natural drainage pathway of the maxillary sinus, under endoscopic guidance. No bacterial inoculum or inflammatory reagents were added, but the success rate for CRS development was increased from $50 \%$ to $100 \%$ of animals ${ }^{(51,89)}$. Cho and colleagues (2018) successfully used the Meroce ${ }^{\circledR}$ nasal obstruction model in rabbits to analyse the transition of the sinonasal microbiota throughout the pathogenesis of CRS and found a significant shift to potential pathogens (such as Pseudomonas and Burkholderia). In addition, the abundance of Corynebacterium was significantly elevated during the chronic phase of the inflammation, which is in accordance with the findings of Wagner Mackenzie et al. (2017) for human CRS studies. Cho et al. also reported a higher bacterial diversity associated with CRS in rabbits compared to healthy controls (the same animal before intervention) in contrast with some previous human studies $^{(12,13,90)}$. A plausible explanation for this discrepancy is that the reduced bacterial diversity in CRS patients could be due to multiple courses of antibiotics prior to recruitment, whereas antibiotics were not administered to the animal model ${ }^{\left({ }^{89}\right)}$. The endoscopically guided nasal obstruction model provides an opportunity for further investigation of microbial communities in CRS and aetiology of inflammatory mucosal disease. It also allows for testing of the effects of antibiotics on the mucous microbiome and observing treatment outcomes in a preclinical setting.

\section{Advantages, limitations and challenges}

The unilateral nasal obstruction model as described by Cho et al. (2018) has considerable potential, offering significant advantages for microbiome research. Developing CRS in a single nostril 
Table 2. Minimal disease features of CRS required in an animal model.

\begin{tabular}{|c|c|c|}
\hline Disease feature & Indicators & Outcome measures \\
\hline $\begin{array}{l}\text { Sinonasal mucosal inflammation persisting for } \\
\text { over } 12 \text { weeks }\end{array}$ & $\begin{array}{l}\text { Inflamed tissue within the sinuses, } \\
\text { Inflammatory cytokines, } \\
\text { Inflammatory cells (e.g. T-cells, B-cell, Macro- } \\
\text { phages) }\end{array}$ & $\begin{array}{l}\text { MRI, micro CT, } \\
\text { histology, IHC, } \\
\text { cytokine analysis, } \\
\text { qPCR TaqMan arrays for inflammatory markers }\end{array}$ \\
\hline Mucus thickening and build-up in the sinuses & Biofilm development & $\begin{array}{l}\text { SEM, CLSM, } \\
\text { micro OCT }\end{array}$ \\
\hline Chronic changes in the tissue & $\begin{array}{l}\text { Epithelial hypertrophy, } \\
\text { Goblet cell hyperplasia, } \\
\text { Epithelial barrier impairment }\end{array}$ & histology \\
\hline $\begin{array}{l}\text { Changes in the sinonasal microbial commu- } \\
\text { nities }\end{array}$ & $\begin{array}{l}\text { Microbial dysbiosis, } \\
\text { Increase in bacterial load }\end{array}$ & 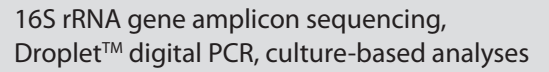 \\
\hline
\end{tabular}

micro OCT = micro-optical coherence tomography

while the other nostril stays healthy mitigates the inter-subject variability that is a significant challenge in microbiome research. However, the extent of intra-subject microbiota variation remains an open question. Site-specific variation in microbial composition has been investigated in human CRS patients and healthy subjects and no significant differences in bacterial abundance or diversity were reported ${ }^{(12)}$. Thus, and since each animal can serve as its own control, one would not anticipate the appropriate number of animals needed to achieve statistical power to be unreasonably high. It also has to be considered that CRS generally is a bilateral disease, although a subset of patients present with single-sided symptoms. No differences regarding the features of unilateral compared to bilateral CRS have been reported.

Furthermore, the exact placement of Merocel $^{\circledR}$ in the middle meatus of the sinus is superior to random placement of nasal packing material as sinus drainage is blocked more effectively, resulting in an increased success rate for development of CRS. It is also more favourable than surgical occlusion as it does not cause mucosal injury and maintains the natural sinus anatomy This transnasal endoscopic approach facilitates reproducibility and improves comparability between studies. Higher success rates for CRS development and reduced risk of bacterial infection in the lower airways also represent ethical improvements. Another substantial benefit is that the model is rhinogenic rather than sinogenic as described by Marks (1997). Marks defines sinogenic models as developing rhinosinusitis from bacterial inoculation or antigen administration to a specific sinus. By contrast, in rhinogenic models, the inflammation is initiated from obstructed sinus drainage, which impairs the natural function of the mucous membrane. This leads to a decreased function of cilia and accumulation of mucus, resulting in bacterial dysbiosis, and therefore represents a more physiologically accurate development of mucosal inflammation ${ }^{(78)}$.
Since in this model occlusion is achieved via a transnasal approach, rabbits would be particularly suitable due to their larger nasal cavities compared to rodents. Animals suffering from pneumonia and epiphora have been reported, which represents a drawback when using rabbits ${ }^{(78)}$. While the improved technique presumably decreases the risk of pneumonia, the possibility of inducing epiphora may still be a challenge.

Major limitations apply when drawing conclusions about mucosal inflammation in humans from animal models of CRS. General differences in the nasal microbiota between animals and humans could be expected due to the animals' natural behaviour. Cho et al. have described the most dominant taxa in their rabbit model of CRS as the same bacterial phyla which can dominate in human studies ${ }^{(12-14)}$. However, it is of note that these similarities are observed on a broad taxonomic assignment and in one single study only. Differences could emerge when looking at an increased level of taxonomic resolution. Besides describing the baseline microbiome in rabbits, Cho et al. found the genus $\mathrm{Co}^{-}$ rynebacterium as a potential CRS-associated biomarker which is in accordance with results from human studies ${ }^{(13,89)}$. This shows that despite potential differences in basic microbial composition, putative disease-associated organisms remain similar.

\section{Non-sentient models}

As an alternative to animal models, in vitro model systems provide some benefits for studying the aetiology and pathophysiology of diseases as they bypass major challenges such as variation among subjects and ethical issues associated with animal models ${ }^{(91)}$. A variety of cell culture methods has been employed to successfully recreate the human sinonasal epithelium ${ }^{(92)}$ including the RPMI 2650 cell line, and monolayer cell cultures, which have been used in studies that obtained nasal tissue from humans ${ }^{(93,94)}$, as well as from rats, rabbits ${ }^{(95)}$, dogs, sheep and

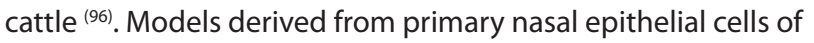


Table 3. Future directions for microbiome research employing animal models of CRS.

\section{Animal models of CRS can be used:}

to test the efficacy of antibiotic and corticosteroid treatment without impairing the standard care for human patients

to track shifts in the microbial community in health and disease throughout long-term studies under high levels of experimental control

in combination with modern network analysis software to detect key microbes associated with health and disease, facilitating exploration of new treatment options in the form of probiotics and targeted antibiotics

to generate reliable data that can be utilised for machine learning in the context of clinical predictive modelling, eventually leading to highly personalised treatment strategies with predicted clinical outcomes

selected patients have been applied in a wide range of studies investigating the cellular inflammatory response in allergic rhinitis ${ }^{\left({ }^{(9)}\right)}$ and CRS ${ }^{(98)}$ and the effects of medical treatment with antibiotics and corticosteroids on chronic inflammation of the nasal epithelium ${ }^{(99-102)}$. However, such cell culture models suffer from several problems, such as the growth of non-epithelial cells, which may potentially result in unreliable data ${ }^{(103)}$. Additionally, cultured nasal epithelial cells lose important characteristics over time such as ciliary function and the ability for mucin production, which represents major limitations especially for long-term studies ${ }^{(104)}$. A current review on models for sinonasal diseases highlights a more advanced 3D cell culturing method in which the cells of the basal side reside within the culture medium while the apical surfaces of cells are surrounded by air ${ }^{\left({ }^{92}\right)}$. The so called air-liquid-interface (ALI) culture mimics the natural environment of nasal epithelial cells and has become the method of choice for such studies ${ }^{(105,106)}$. ALI cultures are still not ideal as models of CRS due to the applied culturing techniques interfering with natural cellular behaviour ${ }^{(92)}$. Recently, more complex culturing systems have been developed to overcome these problems. A 2017 study used a sophisticated microfluidic culturing system, allowing the authors to create a more accurate model of the human sinonasal mucous membrane ${ }^{(107)}$. Developing such a complex culturing system is difficult, costly and time-consuming. However, adequate in vitro models are valuable for testing fundamental conditions of the diseaseassociated micro-environment and thereby help with planning and refinement of subsequent in vivo studies ${ }^{(36)}$.

In vitro models circumvent the translational discrepancy between animal models and humans, hence 3D cell culturing can be considered a powerful tool for future studies on inflammatory nasal disease in humans ${ }^{(92)}$. As this review focuses on model systems especially suitable for research on the nasal microbiome in CRS, it has to be mentioned that presently in vivo models are markedly superior to in vitro cell culture models because the latter cannot mimic the dynamics between inflammation, immune response and the host microbiome ${ }^{(92)}$. Future directions for in vitro modelling with a focus on the investigation of host-microbe interaction in CRS have been summarised recently by De Rudder et al. (2018).

\section{Conclusion}

The current literature reveals a lack of information as to the minimal requirements of animal models for CRS. Suitable models must adequately represent the chronic nature of CRS and include characteristic features of chronic mucosal inflammation such as immune cell infiltration, epithelial hypertrophy and hyperplastic changes. A summary of the minimal disease features of CRS required in an animal model is given in Table 2, together with indicators for these features and methods for their evaluation. In addition, accurate representation and maintenance of the anatomical structure of the paranasal sinuses is necessary, and inflammation should be induced in a way that allows for the natural development of CRS without administration of any antigens or microorganisms.

Microorganisms are a critical factor in human health and disease and dysbiosis in microbial communities is increasingly hypothesised to play an important role in chronic inflammatory mucosal diseases such as CRS. Patients usually undergo medical treatments that change the natural sinonasal microbiome ${ }^{(108)}$, creating a confounding issue in performing basic research of bacterial dysbiosis in humans. In contrast, the employment of animal models allows a high level of experimental control regarding the sinonasal microbiota. Based on the current literature on animal models for chronic sinonasal disease, this review identifies a need for further employment of animal models of CRS for microbiome research. A recent study described the development of a rabbit model of CRS featuring several qualities that make it particularly suitable for microbiological research in a pre-clinical setting ${ }^{(87)}$. This model system represents a further advance of translational research in the field of CRS and allows for alternative treatment strategies and treatment doses to be tested (Table 3). Such results help to optimise the standard practice for managing CRS and hopefully improve the quality of life of CRS patients.

\section{Acknowledgement}

Research on CRS in our laboratories is generously supported by The Garnett Passe and Rodney Williams Memorial Foundation. We thank Vivian Ward for her help with Figure 1.

\section{Authorship contribution}

$\mathrm{CL}$ took the lead in writing the manuscript with the help of $\mathrm{KB}$, MT and RD. DYC contributed with his experience in rabbit and mouse models for airway diseases. 


\section{Conflict of interest}

The authors report no conflicts.

\section{Ethics approval and consent to participate}

Not applicable.

\section{Consent for publication}

Not applicable.

\section{Availability of data and materials}

Not applicable.

\section{Funding}

Research on CRS in our laboratories is generously supported by The Garnett Passe and Rodney Williams Memorial Foundation.

\section{References}

1. Ericsson AC, Crim MJ, Franklin CL. A brief history of animal modeling. Mo med. 2013; 110: 201-205

2. Lavelle GM, White MM, Browne $N$, McElvaney NG, Reeves EP. Animal models of cystic fibrosis pathology: phenotypic parallels and divergences. Biomed Res Int. 2016 2016: 14

3. Aun MV, Bonamichi-Santos R, Arantes-Costa FM, Kalil J, Giavina-Bianchi P. Animal models of asthma: utility and limitations. J Asthma Allergy. 2017; 10: 293-301.

4. Beule A. Epidemiology of chronic rhinosinusitis, selected risk factors, comorbidities, and economic burden. GMS Curr Top Otorhinolaryngol Head Neck Surg. 2015; 14: 13.

5. Blackwell DL, Lucas JW, Clarke TC. Summary health statistics for U.S. adults: national health interview survey, 2012. Vital Health Stat 10. 2014; 1-161.

6. Hastan D, Fokkens WJ, Bachert C, et al. Chronic rhinosinusitis in Europe--an underestimated disease. A GA(2)LEN study. Allergy. 2011; 66: 1216-1223.

7. Shi JB, Fu QL, Zhang H, et al. Epidemiology of chronic rhinosinusitis: results from a cross-sectional survey in seven Chinese cities. Allergy. 2015; 70: 533-539.

8. Boase S, Foreman A, Cleland E, et al. The microbiome of chronic rhinosinusitis: culture, molecular diagnostics and biofilm detection. BMC Infect Dis. 2013: 13: 210

9. Feazel LM, Robertson CE, Ramakrishnan VR, Frank DN. Microbiome complexity and Staphylococcus aureus in chronic rhinosinusitis. Laryngoscope. 2012; 122: 467-472.

10. Abreu NA, Nagalingam NA, Song $Y$, et al. Sinus microbiome diversity depletion and Corynebacterium tuberculostearicum enrichment mediates rhinosinusitis. Sci Transl Med. 2012; 4: 124-151.

11. Aurora R, Chatterjee D, Hentzleman J, Prasad G, Sindwani R, Sanford T. Contrasting the microbiomes from healthy volunteers and patients with chronic rhinosinusitis JAMA Otolaryngol Head Neck Surg. 2013; 139: 1328-1338.

12. Biswas K, Hoggard M, Jain R, Taylor MW Douglas RG. The nasal microbiota in health and disease: variation within and between subjects. Front Microbiol. 2015: 9: 134
13. Wagner Mackenzie B, Waite DW, Hoggard M, Douglas RG, Taylor MW, Biswas K Bacterial community collapse: a meta-analysis of the sinonasal microbiota in chronic rhinosinusitis. Environ Microbiol. 2017; 19: 381-392.

14. Hoggard M, Biswas K, Zoing M, Wagne Mackenzie B, Taylor MW, Douglas RG. Evidence of microbiota dysbiosis in chronic rhinosinusitis. Int Forum Allergy Rhinol. 2016; 7: 230-239.

15. Ramakrishnan VR, Feazel LM, Gitomer SA, I D, Robertson CE, Frank DN. The microbiome of the middle meatus in healthy adults. PLoS One. 2013; 8.

16. Hoggard M, Wagner Mackenzie B, Jain R, Taylor MW, Biswas K, Douglas RG. Chronic rhinosinusitis and the evolving understanding of microbial ecology in chronic inflammatory mucosal disease. Clin Microbiol Rev. 2017; 30: 321-348.

17. Poetker DM, Jakubowski LA, Lal D, Hwang $\mathrm{PH}$, Wright ED, Smith TL. Oral corticosteroids in the management of adult chronic rhinosinusitis with and without nasal polyps: an evidence-based review with recommendations. Int Forum Allergy Rhinol. 2013; 3 104-120.

18. Ramakrishnan VR, Mace JC, Soler ZM, Smith $T L$. Examination of high-antibiotic users in a multi-institutional cohort of chronic rhinosinusitis patients. Int Forum Allergy Rhinol. 2017; 7: 343-351

19. Smith SS, Evans CT, Tan BK, Chandra RK Smith SB, Kern RC. National burden of antibiotic use for adult rhinosinusitis. J Allergy Clin Immunol. 2013; 132: 1230-1232.

20. Barshak MB, Durand ML. The role of infec tion and antibiotics in chronic rhinosinusitis. Laryngoscope Investig Otolaryngol. 2017; 2: 36-42.

21. Kennedy JL, Borish L. Chronic rhinosinusitis and antibiotics: the good, the bad, and the ugly. Am J Rhinol Allergy. 2013; 27: 467-472.

22. Rosenfeld RM, Piccirillo JF, Chandrasekhar SS, et al. Clinical practice guideline (update) adult sinusitis. Otolaryngol Head Neck Surg. 2015; 152: 1-39

23. Young J, De Sutter A, Merenstein D, et al. Antibiotics for adults with clinically diagnosed acute rhinosinusitis: a meta-analysis of individual patient data. Lancet. 2008; 371 908-914
24. Cain RB, Lal D. Update on the management of chronic rhinosinusitis. Infect Drug Resist. 2013; 6: 1-14.

25. Shin HW. Animal models in CRS and pathophysiologic insights gained: a systematic review. Laryngoscope Investig Otolaryngol. 2016; 1: 116-123.

26. London Jr. NR, Lane AP. Innate immunity and chronic rhinosinusitis: what we have learned from animal models. Laryngoscope Investig Otolaryngol. 2016; 1: 49-56.

27. Moore B, Lawson WE, Oury TD, Sisson TH, Raghavendran K, Hogaboam CM. Animal models of fibrotic lung disease. Am J Respir Cell Mol Biol. 2013; 49: 167-179.

28. Shapiro SD. Transgenic and gene-targeted mice as models for chronic obstructive pulmonary disease. Eur Respir J. 2007; 29: 375378

29. Chennupati SK, Chiu AG, Tamashiro E, et al. Effects of an LL-37-derived antimicrobial peptide in an animal model of biofilm Pseudomonas sinusitis. Am J Rhinol Allergy. 2009: 23: 46-51.

30. Gocea A, Taulescu M, Trombitas V, Albu S. Effects of cryotherapy on the maxillary antrostomy patency in a rabbit model of chronic rhinosinusitis. Biomed Res Int. 2013; 2013: 101534

31. Jia M, Chen Z, Guo Y, Chen X, Zhao X Efficacy of silk fibroin-nano silver against Staphylococcus aureus biofilms in a rabbit model of sinusitis. Int J Nanomedicine. 2017: 12: 2933-2939.

32. Tamashiro E, Banks CA, Chen B, et al. In vivo effects of citric acid/zwitterionic surfactant cleansing solution on rabbit sinus mucosa. Am J Rhinol Allergy. 2009; 23: 597-601.

33. Jia M, Chen Z, Du X, Guo Y, Sun T, Zhao X A simple animal model of Staphylococcus aureus biofilm in sinusitis. Am J Rhinol Allergy. 2014; 28: 115-119.

34. Pahl A, Szelenyi S, Brune K. Hypoxia induced chemokine expression in nasal epithelial cells: development of an in vitro model for chronic rhinosinusitis. Altex. 2006; 23: 59-63.

35. Ball SL, Suwara MI, Borthwick LA, Wilson JA, Mann DA, Fisher AJ. How reliable are sinonasal cell lines for studying the pathophysiology of chronic rhinosinusitis? Ann Otol Rhinol Laryngol. 2015; 124: 437-442.

36. De Rudder C, Calatayud Arroyo M, Lebeer S, Van de Wiele T. Modelling upper respira- 
tory tract diseases: getting grips on hostmicrobe interactions in chronic rhinosinusitis using in vitro technologies. Microbiome. 2018; 6: 75

37. Hilding AC. Experimental sinus surgery: effects of operative windows on normal sinuses. Ann Otol Rhinol Laryngol. 1941; 50: 379-392.

38. Coates G, Ersner MS. Regeneration of the mucous membrane of the frontal sinus after its surgical removal (in the dog). Arch Otolaryngol. 1930; 12: 642-648.

39. Boase S, Jervis-Bardy J, Cleland E, Pant H, Tan L, Wormald PJ. Bacterial-induced epithelial damage promotes fungal biofilm formation in a sheep model of sinusitis. Int Forum Allergy Rhinol. 2013; 3: 341-348.

40. Boase S, Valentine R, Singhal D, Tan LW, Wormald PJ. A sheep model to investigate the role of fungal biofilms in sinusitis: fungal and bacterial synergy. Int Forum Allergy Rhinol. 2011; 1: 340-347.

41. Drilling A, Morales S, Boase S, et al. Safety and efficacy of topical bacteriophage and ethylenediaminetetraacetic acid treatment of Staphylococcus aureus infection in a sheep model of sinusitis. Int Forum Allergy Rhinol. 2014; 4: 176-186.

42. Rajiv S, Drilling A, Bassiouni A, James C, Vreugde S, Wormald PJ. Topical colloidal silver as an anti-biofilm agent in a Staphylococcus aureus chronic rhinosinusitis sheep model. Int Forum Allergy Rhinol. 2015; 5: 283-288.

43. Chang EH, Pezzulo AA, Meyerholz DK, et al. Sinus hypoplasia precedes sinus infection in a porcine model of cystic fibrosis. Laryngoscope. 2012; 122: 1898-1905.

44. Burns AR, Hosford SP, Dunn LA, Walker DC, Hogg JC. Respiratory epithelial permeability after cigarette smoke exposure in guinea pigs. J Appl Physiol. 1989; 66: 2109-2116.

45. Tatar A, Korkmaz M, Yayla M, et al. The potential role of amlodipine on experimentally induced bacterial rhinosinusitis. Braz J Otorhinolaryngol. 2017; 83: 619-626.

46. Tillie-Leblond I, Gosset P, Le Berre R, et al Keratinocyte growth factor improves alterations of lung permeability and bronchial epithelium in allergic rats. Eur Respir J. 2007; 30: 31-39.

47. Khalmuratova R, Lee M, Kim DW, Park JW, Shin HW. Induction of nasal polyps using house dust mite and Staphylococcal enterotoxin B in C57BL/6 mice. Allergol Immunopathol (Madr). 2016; 44: 66-75.

48. Kim DY, Lee SH, Carter RG, Kato A, Schleimer $\mathrm{RP}$, Cho $\mathrm{SH}$. A recently established murine model of nasal polyps demonstrates activation of $b$ cells, as occurs in human nasal polyps. Am J Respir Cell Mol Biol. 2016; 55: 170-175.

49. Kim JH, Yi JS, Gong $C H$, Jang $Y J$. Development of Aspergillus protease with ovalbumin-induced allergic chronic rhinosinusitis model in the mouse. Am J Rhinol Allergy. 2014; 28: 465-470

50. Peltola VT, Boyd KL, McAuley JL, Rehg JE,
McCullers JA. Bacterial sinusitis and otitis media following influenza virus infection in ferrets. Infect Immun. 2006; 74: 2562-2567.

51. Liang $\mathrm{KL}$, Jiang RS, Wang J, et al. Developing a rabbit model of rhinogenic chronic rhinosinusitis. Laryngoscope. 2008; 118: $1076-$ 1081.

52. Migliavacca RO, Piltcher OB, Kliemann LM, et al. An experimental model of chronic rhinosinusitis in rabbits without bacterial inoculation. Acta Cir Bras. 2014; 29: 313-319.

53. Kirkeby S, Hammer AS, Hoiby N, Salomonsen CM. Experimental Pseudomonas aeruginosa mediated rhino sinusitis in mink. Int J Pediatr Otorhinolaryngol. 2017; 96: 156-163.

54. Costa HO, Ruschi e Luchi GE, Augusto AG, Castro M, de Souza FC. Comparative study of several sinusitis experimental modelling techniques in rabbits. Braz J Otorhinolaryngol. 2007; 73: 627-631.

55. Lindsay R, Slaughter T, Britton-Webb J, et al. Development of a murine model of chronic rhinosinusitis. Otolaryngol Head Neck Surg. 2006; 134: 724-730

56. Hong SL, Zhang YL, Kim SW, et al. Interleukin-17A-induced inflammation does not influence the development of nasal polyps in murine model. Int Forum Allergy Rhinol. 2015; 5: 363-370.

57. Xie M. A comparative experimental study between recombinant active gene 1-deficient mice and C57BL/6 mice model of acute bacterial rhinosinusitis. Zhonghua er bi yan hou ke za zhi. 2002; 37: 23-26.

58. Kobayashi Y, Watanabe M, Okada Y, et al. Hydrocephalus, situs inversus, chronic sinusitis, and male infertility in dna polymerase-deficient mice: possible implication for the pathogenesis of immotile cilia syndrome. Mol Cell Biol. 2002; 22: 2769-2776.

59. Vogel P, Read R, Hansen GM, Freay LC, Zambrowicz BP, Sands AT. Situs inversus in Dpcd/Poll-/-, Nme7-/- , and Pkd111-/- mice. Vet Pathol. 2010; 47: 120-131.

60. Vaure C, Liu Y. A comparative review of Tolllike receptor 4 expression and functionality in different animal species. Front Immunol. 2014; 5: 316.

61. Smolich JJ, Stratford BF, Maloney JE, Ritchie BC. New features in the development of the submucosal gland of the respiratory tract. J Anat. 1978; 127: 223-238.

62. Tomoji M, Tadao S. Rat resources in biomedical research. Curr Pharm Biotechnol. 2009; 10: 214-220.

63. Tipirneni KE, Cho DY, Skinner DF, et al. Characterization of primary rat nasal epithelial cultures in CFTR knockout rats as a model for CF sinus disease. Laryngoscope. 2017; 127: 384-391.

64. Kim HC, Lim JY, Kim S, Kim JH, Jang YJ. Development of a mouse model of eosinophilic chronic rhinosinusitis with nasal polyp by nasal instillation of an Aspergillus protease and ovalbumin. Eur Arch Otorhinolaryngol. 2017; 274: 3899-3906.

65. Jacob A, Faddis BT, Chole RA. Chronic bacterial rhinosinusitis: Description of a mouse model. Arch Otolaryngol Head Neck Surg. 2001; 127: 657-664.

66. Lee $M$, Kim DW, Yoon $H$, et al. Sirtuin 1 attenuates nasal polypogenesis by suppressing epithelial-to-mesenchymal transition. J Allergy Clin Immunol. 2016; 137: 87-98.

67. Jin J, Rha KS, Kim DW, Kim YM. IL-17C expression in nasal epithelial cells of chronic rhinosinusitis with nasal polyposis. Eur Arch Otorhinolaryngol. 2014; 271: 1097 1105.

68. Kim DK, Jin HR, Eun KM, et al. The role of interleukin-33 in chronic rhinosinusitis. Thorax. 2017; 72: 635-645.

69. Kim DW, Eun KM, Jin HR, Cho SH, Kim DK. Prolonged allergen exposure is associated with increased thymic stromal lymphopoietin expression and Th2-skewing in mouse models of chronic rhinosinusitis. Laryngoscope. 2016; 126: 265-272.

70. Mulligan JK, Pasquini WN, Carroll WW, et al. Dietary vitamin D3 deficiency exacerbates sinonasal inflammation and alters local 25(OH)D3 metabolism. PLoS One. 2017; 12: 0186374.

71. Shin HW, Kim DK, Park MH, et al. IL-25 as a novel therapeutic target in nasal polyps of patients with chronic rhinosinusitis. J Allergy Clin Immunol. 2015; 135: 1476-1485.

72. Martens K, Pugin B, De Boeck I, et al. Probiotics for the airways: Potential to improve epithelial and immune homeostasis. Allergy. 2018; 73: 1954-1963.

73. Mapara M, Thomas BS, Bhat KM. Rabbit as an animal model for experimental research. Dent Res J (Isfahan). 2012; 9: 111-118.

74. Campos CA, Dolci EL, Silva L, Dolci JE, Campos CA, Dolci RL. Osteitis and mucosal inflammation in a rabbit model of sinusitis. Braz J Otorhinolaryngol. 2015; 81: 312-320.

75. Kara CO. Animal models of sinusitis: relevance to human disease. Curr Allergy Asthma Rep. 2004; 4: 496-499.

76. Dolci EL, Campos CA, Silva L, Dolci RL, Dolci JE. Evaluation of the ability of an experimental model to induce bacterial rhinosinusitis in rabbits. Braz J Otorhinolaryngol. 2014; 80: 480-489.

77. Dufour X, Kauffmann-Lacroix C, Goujon JM, Grollier G, Rodier MH, Klossek JM. Experimental model of fungal sinusitis: a pilot study in rabbits. Ann Otol Rhinol Laryngol. 2005; 114: 167-172.

78. Marks SC. Acute sinusitis in the rabbit: A new rhinogenic model. Laryngoscope. 1997; 107: 1579-1585.

79. Sejima T, Kajiwara D, Kikuchi H, Imayoshi S, Yamauchi T, Ichimura K. Experimentally induced eosinophilic polyps in rabbit sinuses. Am J Rhinol Allergy. 2010; 24: 341-347.

80. Maeyama T. A study of experimental sinusitis in rabbits. Auris Nasus Larynx. 1981; 8: 87-97.

81. Drettner B, Johansson P, Kumlien J. Experimental acute sinusitis in rabbit. $\mathrm{A}$ study of mucosal blood flow. Acta oto-laryngologica. 1987; 103: 432-434. 
82. Cho DY, Hoffman K, Skinner D, et al. Tolerance and pharmacokinetics of a ciprofloxacin-coated sinus stent in a pre-clinical model. Int Forum Allergy Rhinol. 2017; 7: 352-358.

83. Cho DY, Lim DJ, Mackey C, et al. Pre-clinical therapeutic efficacy of the ciprofloxacineluting sinus stent for Pseudomonas aeruginosa sinusitis. Int Forum Allergy Rhinol. 2018; 8: 482-489.

84. Rings DM, Rojko J. Naturally occurring nasal obstructions in 11 sheep. Cornell Vet. 1985; 75: 269-276.

85. Thomas DC, Wormald PJ. Standardization of diagnostic criteria for eosinophilic chronic rhinosinusitis in the Oestrus ovis infected sheep model. Am J Rhinol. 2007; 21: 551555 .

86. Gardiner Q, Oluwole M, Tan L, White PS. An animal model for training in endoscopic nasal and sinus surgery. J Laryngol Otol. 1996; 110.

87. Ha KR, Psaltis AJ, Tan L, Wormald P-J. A sheep model for the study of biofilms in rhinosinusitis. Am J Rhinol. 2007: 21: 339-345.

88. Athanasiadis $T$, Beule $A G$, Robinson BH, Robinson SR, Shi Z, Wormald PJ. Effects of a novel chitosan gel on mucosal wound healing following endoscopic sinus surgery in a sheep model of chronic rhinosinusitis. Laryngoscope. 2008; 118: 1088-1094.

89. Cho D-Y, Mackey C, Van Der Pol WJ et al. Sinus microanatomy and microbiota in a rabbit model of rhinosinusitis. Front Cell Infect Microbiol. 2018; 7: 540 .

90. Wilson MT, Hamilos DL. The nasal and sinus microbiome in health and disease. Curr Allergy Asthma Rep. 2014; 14: 485

91. Masters JR. Human cancer cell lines: fact and fantasy. Nat Rev Mol Cell Biol. 2000; 1 233-236.

92. Al-Sayed AA, Agu RU, Massoud E. Models for the study of nasal and sinus physiology in health and disease: A review of the literature. Laryngoscope Investig Otolaryngol. 2017; 2: 398-409.

93. Hussain R, Hugosson S, Roomans GM. Isolation and culture of primary human nasal epithelial cells from anesthetized nasal epithelia. Acta oto-laryngologica. 2014; 134: 296-299.

94. Wu R, Yankaskas J, Cheng E, Knowles MR, Boucher R. Growth and differentiation of human nasal epithelial cells in culture. Serum-free, hormone-supplemented medium and proteoglycan synthesis. Am Rev Respir Dis. 1985; 132: 311-320.

95. Steele VE, Arnold JT. Isolation and long-term culture of rat, rabbit, and human nasal turbinate epithelial cells. In Vitro Cell Dev Bio Anim. 1985; 21: 681-687.

96. Schmidt MC, Peter H, Lang SR, Ditzinger G, Merkle HP. In vitro cell models to study nasal mucosal permeability and metabolism. Adv Drug Deliv Rev. 1998; 29: 51-79.

97. Ayars GH, Altman LC, McManus MM, et al. Injurious effect of the eosinophil peroxide-hydrogen peroxide-halide system and major basic protein on human nasal epithelium in vitro. Am Rev Respir Dis. 1989; 140 125-131.

98. Kenney JS, Baker C, Welch MR, Altman LC Synthesis of interleukin-1 alpha, interleukin-6, and interleukin-8 by cultured human nasal epithelial cells. J Allergy Clin Immunol Pract. 1994; 93: 1060-1067.

99. Bleier BS, Mulligan RM, Schlosser RJ. Primary human sinonasal epithelial cell culture model for topical drug delivery in patients with chronic rhinosinusitis with nasal polyposis. J Pharm Pharmacol. 2012; 64: 449456.

100. Fujita K, Shimizu T, Majima Y, Sakakura Y Effects of macrolides on interleukin-8 secretion from human nasal epithelial cells. Eur Arch Otorhinolaryngol. 2000; 257: 199-204.

101. Miyanohara T, Ushikai M, Matsune S, Ueno K, Katahira S, Kurono Y. Effects of clarithromycin on cultured human nasal epithelial cells and fibroblasts. Laryngoscope. 2000; 110: 126-131.

102. Suzuki H, Shimomura A, Ikeda K, Furukawa M, Oshima T, Takasaka T. Inhibitory Effect of macrolides on interleukin-8 secretion from cultured human nasal epithelial cells. Laryngoscope. 1997; 107: 1661-1666.
103. Van Scott MR, Yankaskas JR, Boucher RC. Minireview: Culture of airway epithelial cells: Research techniques. Exp Lung Res. 1986; 11: 75-94.

104. Jorissen M, Van der Schueren B, Van den Berghe $\mathrm{H}$, Cassiman J-J. The preservation and regeneration of cilia on human nasal epithelial cells cultured in vitro. Eur Arch Otorhinolaryngol. 1989; 246: 308-314.

105. Lee MK, Yoo JW, Lin H, et al. Air-liquid interface culture of serially passaged human nasal epithelial cell monolayer for in vitro drug transport studies. Drug Deliv. 2005; 12 : 305-311.

106. Muller L, Brighton LE, Carson JL, Fischer WA 2 nd, Jaspers I. Culturing of human nasal epithelial cells at the air liquid interface. J Vis Exp. 2013; 80

107. Na K, Lee M, Shin HW, Chung S. In vitro nasal mucosa gland-like structure formation on a chip. Lab Chip. 2017; 17: 1578-1584.

108. Liu CM, Soldanova K, Nordstrom L, et al. Medical therapy reduces microbiota diversity and evenness in surgically recalcitrant chronic rhinosinusitis. Int Forum Allergy Rhinol. 2013; 3: 775-781.

Richard G. Douglas, Professor Department of Surgery

Level 12

Auckland City Hospital

Park Road Grafton

Auckland 1023

New Zealand

Tel: + 6499231658

Fax: +643779656

E-mail:

richard.douglas@auckland.ac.nz

ISSN: 2589-5613 / @2019 The Author(s). This work is licensed under a Creative Commons Attribution 4.0 International License. The images or other third party material in this article are included in the article's Creative Commons license, unless indicated otherwise in the credit line; if the material is not included under the Creative Commons license, users will need to obtain permission from the license holder to reproduce the material. To view a copy of this license, visit http://creativecommons.org/ licenses/by/4.0/ 